\title{
This Strange Creature: Plato and Conversion Experiences
}

\author{
Joe Cimakasky ${ }^{1, *}$, Joseph J. Romano ${ }^{2, *}$ and Kristian Sheeley ${ }^{3, *}$ \\ 1 Unaffiliated, Phoenixville, PA 19460, USA \\ 2 Department of Philosophy, Cabrini University, Radnor, PA 19087, USA \\ Department of Philosophy, University of Kentucky, Lexington, KY 40506, USA \\ * Correspondence: joecimakasky@gmail.com (J.C.); jromano@cabrini.edu (J.J.R.); Sheeleyk@uky.edu (K.S.)
}

Citation: Cimakasky, Joe, Joseph J. Romano, and Kristian Sheeley. 2021. This Strange Creature: Plato and Conversion Experiences. Religions 12: 847. https://doi.org/10.3390/ rel12100847

Academic Editors: Eva Anagnostou, Georgios Steiris and Georgios Arabatzis

Received: 19 August 2021 Accepted: 5 October 2021 Published: 9 October 2021

Publisher's Note: MDPI stays neutral with regard to jurisdictional claims in published maps and institutional affiliations.

Copyright: (C) 2021 by the authors. Licensee MDPI, Basel, Switzerland. This article is an open access article distributed under the terms and conditions of the Creative Commons Attribution (CC BY) license (https:/ / creativecommons.org/licenses/by/ $4.0 /)$.

\begin{abstract}
In Plato's corpus, the Greek word $\varepsilon^{\prime} \xi \alpha^{\prime} \varphi v \eta \varsigma$ appears precisely thirty-six times. Translated generally as "all of a sudden" or "the instant" in his Parmenides, है $\alpha_{i}^{\prime} \varphi v \eta \zeta$ emerges in some of the most significant passages of Plato's dialogues. Put simply, દ̇ $\alpha i \varphi \vee \eta \zeta$ connotes illumination of the highest realities and philosophical conversion experience. In addition to providing a review of

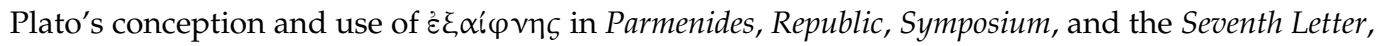
our paper brings an ancillary link to light. Namely, the appearance of $\varepsilon^{\xi} \xi \alpha^{i} \varphi \vee \eta \varsigma$ as a mark for conversion experiences in the New Testament's Acts of the Apostles and Plotinus's Enneads. We reveal how the same pattern and employment of $\varepsilon^{\xi} \alpha \hat{i} \varphi \vee \eta \zeta$ established by Plato emerge in both Acts and the Enneads. This pattern suggests a prolonged period of thinking and training, followed by a

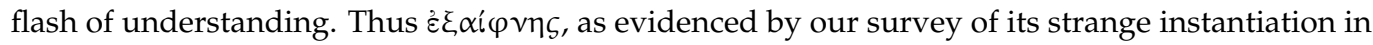
Plato's dialogues and then subsequently in Acts and the Enneads, becomes a sign for enlightenment, assimilation with the divine, and conversion experience.
\end{abstract}

Keywords: conversion experience; illumination; training; suddenly; participation; ideas; excellence; beauty itself; the good

\section{Introduction}

Will this be our life-long work, simply to convert to the pursuit of excellence those who have not yet converted so that they in turn may convert others?

\section{Plato, Clitophon 408e}

The earliest known civilization in human history tells of the dramatic conversion of Gilgamesh. Gilgamesh ruled the magnificent city of Uruk with a tyrannical hand. Half God and half mortal, he terrorized all who opposed him, ruling by fear rather than by law. When his only friend, Enkidu, was killed, Gilgamesh plunged into the depths of depression. The thought of life-ending mortality seemed incomprehensible to him. After days of inconsolable grief, he vowed to conquer death itself by seeking the one mortal who was granted eternal life-Utnapishtim, the sole survivor of the great Sumerian flood. On his quest, he was warned: "No man born of woman has done what you have asked. No mortal man has gone into the mountain with its twelve leagues of darkness. In it there is no light, and the heart is oppressed with darkness". Gilgamesh resolved to take the arduous journey through 36 miles of dark depression, weakened physically and mentally distraught, until he finally saw the light. A lovely spirit guide said to him:

"Gilgamesh, where are you hurrying to? You will never find the life you are looking for. When the gods created man they allotted to him death, but life they retained for their own keeping. As for you, Gilgamesh, fill your belly with good things; day and night, dance, be merry, rejoice. Let your clothes be fresh, bathe yourself in water, cherish the little child that holds your hand, and make your wife happy in your embrace; for this too is the lot of man". 
Gilgamesh's quest for immortality was unsuccessful. It was just beyond his grasp, and according to the cuneiform tablets, he accepted his fate and returned to Uruk. But he was then different. The arduous journey did not grant him immortality, but Gilgamesh did achieve an illumination of the human condition, and by this measure, he experienced a conversion experience, a reorientation of his life.

Examples of reorientation-conversion experiences-abound in ancient literature, from Gilgamesh to St. Augustine in Book VIII of his Confessions (Augustine 1998). By "conversion experience," we mean a profound change from one way of life to another. In other words, we use the term as it is commonly and etymologically understood, as a "turning around". ${ }^{1}$ Gilgamesh underwent an ordeal, a demanding exercise, and as a result, he gained an insight that prompted his return to Uruk, fate accepted, and the turning around of his life's purpose. In both religious and philosophical contexts, conversion involves a fundamental change or reorientation in one's way of life and values. The enlightened one reorganizes her life and priorities according to a newly discovered conception of the good, irrespective of whether the conception derives from a religious teaching or philosophical reflection. ${ }^{2}$ Her perspective changes such that she now regards her previous values and way of life as less valuable than they once seemed. Similarly, she now sees a new set of values and way of life as more worthy than what formerly appeared.

Moreover, the convert recognizes such a reorientation as highly beneficial. In general, then, conversion or illumination experiences embrace the notion of beneficial change, and this is the operative meaning in the examples to follow. Thus, for the purposes of this paper, we use the expressions "conversion experience" and "illumination experience" interchangeably, and they simply designate a beneficial change from ignorance to wisdom, sin to righteousness, from a worse way of life to a better one, or all of these at once. Importantly, this notion of beneficial change is at play in Plato's dialogues, and we shall see Plato's model materialize in subsequent ancient religious and philosophical texts as evidenced by the appearance of the Greek $\varepsilon^{\xi} \xi \alpha i \varphi \vee \eta \zeta$.

Relative to the vast scholarship concerning the concepts and doctrines accepted conventionally as key to understanding Plato's philosophy, few examine his strange use of

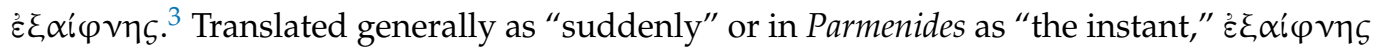
surfaces in some of the most crucial and well-known passages of Plato's dialogues. In Republic VII, the liberated prisoner "suddenly" ( $\xi \xi \alpha \varphi \vee \eta \varsigma)$ rises and looks up "toward the light" of the Good (515c6-7). In his Seventh Letter, Plato describes philosophical illumination as happening "suddenly" ( $\xi \xi \alpha i \varphi \vee \eta \varsigma)$, just as a scintillating flash issues forth from a newly lit fire (341c8-d1). Likewise, in Symposium, the true lover, who, "in the right order and correctly," grasps beautiful things, "all of a sudden" ( $\xi \xi \alpha \varphi \vee \eta ऽ) ~ c a t c h e s$ a glimpse of Beauty itself (210e6-211a1). While Plato's Parmenides offers the only conceptually sustained, thematic treatment of $\dot{\varepsilon} \xi \alpha i \varphi v \eta \varsigma$ in the dialogues, the most remarkable examples of the thirty-six appearances of ह' $\xi \alpha i \varphi \vee \eta \zeta$ in Plato's works illustrate a methodical, step-by-step process of philosophical education climaxing with a sudden and illuminating conversion experience. Said another way, $\varepsilon_{\xi} \alpha^{\prime} \varphi \vee \eta ऽ$ signifies the climax of the hard work entailed in the rigorous Platonic dialectic.

In addition to providing a review of Plato's conception and use of '̇ं $\alpha^{\prime} \iota \varphi \vee \eta \varsigma$ in Parmenides, Republic, Symposium, and the Seventh Letter, the following brings an ancillary link to light, namely, the appearance of $\dot{\varepsilon} \xi \alpha i \varphi v \eta \varsigma$ as a mark for conversion experiences in Acts of the Apostles and Plotinus's Enneads. We reveal how the same pattern and employment of $\dot{\varepsilon} \xi \alpha i \varphi v \eta \varsigma$ established by Plato emerge in both Acts and the Enneads. Simply put, this pattern suggests a prolonged period of thinking and training, followed by a flash of understanding and conversion experience.

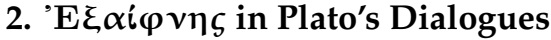

'E $\xi \alpha i \varphi v \eta \zeta$ appears fifty-nine times in extant Greek works previous to or contemporaneous with Plato. Homer's Iliad features the earliest appearances. In addition to Homer,

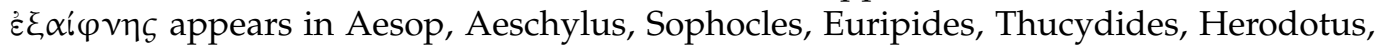


Isocrates, Aristophanes, and Xenophon, among others. Upon examining these passages, the broad brushstrokes of a pattern emerge. Nearly every appearance of $\dot{\varepsilon} \xi \alpha i \varphi \vee \eta \zeta$ in extant Greek literature prior to and contemporaneous with Plato reveals the following: (1) a swift transformation or change and (2) negative consequences resulting from this swift transformation or change. Thus, the appearances of $\dot{\xi} \xi \alpha^{\prime} \varphi \vee \eta \varsigma$ prior to Plato show the term held a menacing connotation. ${ }^{4}$ In other words, events happening "suddenly" generally produced tragic results.

Plato maintains the element of transformation with respect to $\dot{\varepsilon} \xi \alpha i \varphi \vee \eta \varsigma$, but he reorients the tragic association typically accompanying the term. For Plato, $\varepsilon^{\xi} \xi \alpha \varphi \varphi \vee \eta \varsigma$ becomes a sign of enlightenment or illumination of the highest realities, e.g., the Platonic Forms or Ideas. The lengthy character and intellectual training exemplifying Plato's notion of philosophical education reaches its zenith with a sudden reorientation, or conversion, of the soul. Consequently, an understanding of Plato's philosophical project and the protreptic nature of education requires a familiarity with Plato's peculiar use of $\varepsilon^{\prime} \xi \alpha i \varphi v \eta \zeta$. In what follows, we survey four instances of the term in Plato's works, which illustrate how ¿̇ $\alpha^{i} \varphi \vee \eta \zeta$ represents reorientation and the peak of philosophical enlightenment.

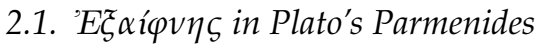

Plato's Parmenides offers the only sustained treatment of $\varepsilon \xi \alpha i \varphi \vee \eta \zeta$ in the dialogues. A whole host of questions involving the Ideas and participation $(\mu \varepsilon \varepsilon \varepsilon \xi\llcorner\zeta)$ arise when discussing Parmenides and the so-called "later dialogues," e.g., Theaetetus, Sophist, Statesman, etc., and the purpose of this paper precludes a comprehensive examination of these questions. Nevertheless, the nature of the ensuing analysis compels us to state our position clearly and concisely regarding the status of the Ideas and participation. In general terms, we maintain the Ideas are not merely isolated, standalone, and immoveable entities but require a relational, interactive dynamic as well. In other words, the Ideas must in some sense move and participate with each other. ${ }^{5}$ Despite the orthodox view concerning the immobility of the Ideas, the Ideas considered in motu corresponds nicely with the Visitor's suggestive question from Plato's Sophist 248e7-249a2: “But for heaven's sake, are we going to be convinced that it's true that change, life, soul, and intelligence are not present in that which wholly is, and that it neither lives nor thinks, but stays changeless, solemn, and holy, without any understanding?" Furthermore, we contend participation is understood best by taking a top-down approach, i.e., determining how the Ideas participate with each other sheds lights on how all participants, including humans, might participate in the Ideas. Finally, we maintain the Parmenides affirms the necessity of relational Ideas, and the treatment of $\dot{\xi} \xi \alpha^{i} \varphi \vee \eta \zeta$ offers a key to understanding how the Ideas participate with one another. $^{6}$

Translated as "the sudden" or "the instant," $\dot{\xi} \xi \alpha_{i} \varphi \vee \eta \zeta$ surfaces in the critical third hypothesis of the training exercise constituting the latter two-thirds of the dialogue. While interpretations of the dialogue vary considerably, most scholars agree the third hypothesisor "hypothesis IIa" or "appendix" or "insert hypothesis"—is highly significant.7 Again, this is the only passage in all of Plato's dialogues that explains the curious function and phenomenon of $\varepsilon^{\xi} \xi \alpha i \varphi \vee \eta \zeta$. As the lone numbered hypothesis, the $\varepsilon^{\xi} \xi \alpha i \varphi \vee \eta \zeta$ section of Parmenides commences rather strangely: "Let's speak of it yet a third ( $\tau$ í $\tau$ ov) time," begins Parmenides (155e4). ${ }^{8}$ A few moments later, Parmenides employs rest and motion to identify the perplexities surrounding transition from one state to another. Because, as Parmenides wonders, if something must always be either in motion or at rest, exactly "when" does this transition occur? Since something must always be in either motion or rest, the moment of change requires a suspension of both rest and motion to complete the transition. If change cannot occur in time, then it must happen in "no time" at all.

Is there, then, this strange ( $\ddot{\alpha} \tau$ o $\pi \mathrm{o} v)$ thing in which it might be, just when it

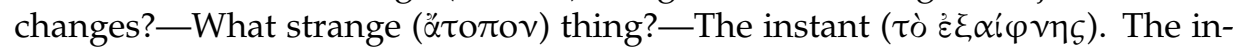
stant ( $\left.\dot{\xi} \xi \alpha^{i} \varphi \vee \eta \varsigma\right)$ seems to signify something such that changing occurs from it to each of two states. For a thing doesn't change from rest while rest continues, or 


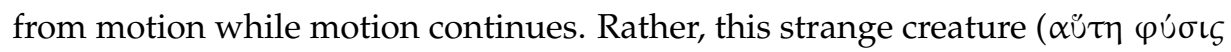

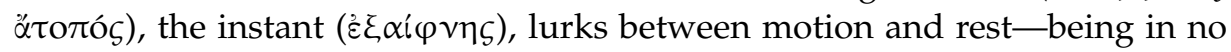
time at all-and to it and from it the moving thing changes to resting and the resting thing changes to moving.--It looks that way.-And the one, if in fact it both rests and moves, could change to each state-for only in this way could it do both. But in changing, it changes at an instant ( $\varepsilon \xi \alpha(\varphi \vee \eta \zeta)$, and when it changes, it would be in no time at all, and just then it would be neither in motion nor at rest.-No, it wouldn't. (156d1-156e7)

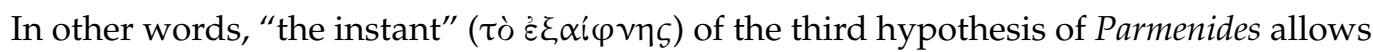
for and facilitates participation among the Ideas themselves, e.g., from rest to motion and motion to rest. As Parmenides suggests, "this strange creature" — the instant ( $\tau$ ò

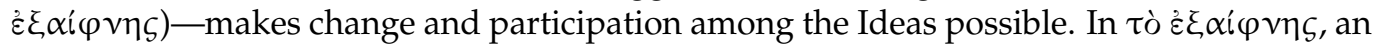
Idea would be neither at rest nor in motion, and this peculiar timelessness would provide an "opening" through which the transition from motion to rest could proceed without obtaining either rest or motion because neither state emerges in the instant. ${ }^{9}$ Thus, the interplay or participation between and among the Ideas happens suddenly, in an instant

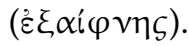

The instant animates the Ideas as they move "into" and "out of" when considered from this timeless perspective, the Ideas are the static, fixed, eternal beings as conventionally understood. The Ideas, however, to be at all, must in some sense move. In other words, any Idea must share or participate in Being in order to be. Thus, an Idea must instantiate another Idea by way of participation through the instant. An Idea participating in another Idea goes "outside itself," so to speak, to another Idea, and thus, it changes or undergoes a kind of transition from the limited one of the first hypothesis to the unlimited one of the second hypothesis, only not at different times but eternally. The Ideas must forever enter "within" and emerge "from" the timeless instant in order to be or participate in Being itself. ${ }^{10}$ When considered from this perspective, i.e., while "in" the instant, the Ideas are the conventionally understood eternal, timeless, unchanging Forms. Changeable, perceptible things manifest this activity by becoming other (or changing) temporally, and they are, "a moving image of eternity" (Timaeus, 37d5). Put another way, the becoming of perceptible things mirrors the being of the intelligible Ideas. Ultimately, the instant ( $\tau \dot{o}$ ध $\xi \alpha i \varphi \vee \eta \varsigma)$ functions as the locus of this dynamic activity: participation.

As mentioned above, Parmenides presents the only sustained, thematic treatment of $\varepsilon \xi \alpha i \varphi \vee \eta \zeta$ in the dialogues, but as demonstrated in the brief survey below, Plato consistently employs $\xi \xi \alpha \varphi \varphi \vee \zeta$ in celebrated passages of other dialogues, and we contend these appearances signify human cognition or participation with the Ideas. While in the Parmenides, "the instant" symbolizes metaphysical change and participation among the Ideas, its emergence in other dialogues signifies psychological change as humans catch sight of the Ideas and reorient their lives.

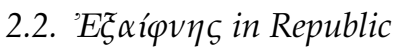

Justice and goodness enliven the discussion in Plato's Republic. To establish goodness in Kallipolis, the beautiful city, the philosopher-king must become good or see the Good ( $\tau \grave{\alpha} \alpha \gamma \alpha \theta o ́ v)$, as he alone will possess the requisite training and capacity "to embrace the thing itself" (480a10-11). Plato both describes the training prosaically, e.g., rigorous studies in arithmetic, geometry, astronomy, practical political affairs, etc., and poetically in Republic VII. The poetic account of the philosopher-king's training constitutes the most famous myth in Plato's corpus and probably the most well-known passage in the history of philosophy: the allegory of the cave. The cave allegory represents the crowning moment of the philosopher-king's education and training, and if participation does indeed happen in an instant, then one could anticipate an appearance of $\dot{\varepsilon} \xi \alpha^{\prime} \varphi \vee \eta \zeta$ in Republic VII.

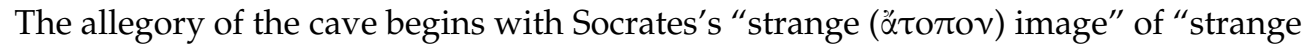

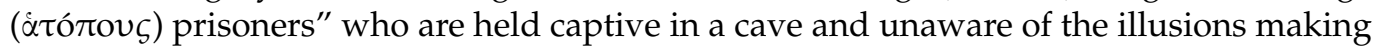
up their shared reality (515a2). Socrates claims his tale concerns the "effect of education 
and of the lack of it on our nature," and perhaps most chillingly: these "strange" prisoners are just "like us" (514a1-2 and 515a2). Fortuitously, a prisoner becomes unchained, and

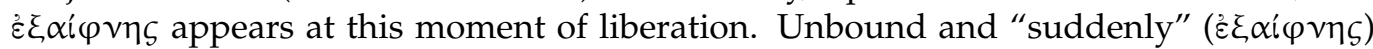
forced to rise, the prisoner struggles to turn his head and "look up toward the light" (515c6-7). The prisoner is "pained and irritated" when forced up the "rough, steep path" out of the cave and into the sunlight (515e5-7). Before long, he would see the sun itself and grasp how it directs and "governs everything in the visible world" (516b4-8). He would understand the sun, i.e., the Good, causes all things. He would know the Idea of the Good, acknowledging it as the source of "truth and understanding" and all that is "correct and beautiful" (517c1-4). Ultimately, Plato's use of '̇ं $\alpha i \varphi \vee \eta \varsigma$ at the precise moment of liberation in the cave allegory reflects its appearance in Parmenides. Sudden

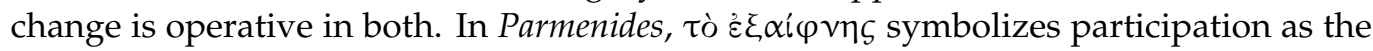
Ideas separate and combine with each other, while in the allegory of the cave, $\varepsilon^{\prime} \xi \alpha i \varphi \vee \eta \zeta$ signifies the moment when the philosopher "ascends that ascent" and sees the Good itself (519a10). ${ }^{11}$

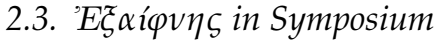

Plato's encomium to love (है $\rho \omega \varsigma$ ), Symposium, finds Socrates introducing a soothsayer from Mantinea, a woman named Diotima, who taught him the "art of love" ( $\tau \dot{\alpha} \varepsilon \hat{\varepsilon} \rho \omega \tau \iota \kappa \alpha ́)$ (201d2-5). "E $\xi \alpha i \varphi \vee \eta \varsigma$ emerges in Symposium right before Diotima reveals the goal of all loving. She insists that Socrates "pay attention" as she proceeds to disclose how "all of a sudden" ( $\xi \xi \alpha i \varphi \vee \eta \varsigma)$ the properly guided lover will "catch sight" of something "wonderfully beautiful" (210e3-7).

Diotima's account of the true nature of love concludes with an erotic ascensionparallel to the ascent described in the allegory of the cave-and the revelation of "the final and highest mystery" (210a3). According to Diotima, the lover desires one body and gives birth to beautiful ideas, and this, in turn, leads him to acknowledge the beauty of all bodies. He then realizes that beautiful souls possess even more beauty than bodies, and the beauty of these souls is due to the laws and customs of the city. Next, his gaze centers upon the many kinds of knowledge cultivating the beautiful customs and laws. Recognizing the beauty of knowledge itself, he is inspired to give birth to "many gloriously beautiful ideas and theories, in unstinting love of wisdom" (210d1-6). At this point, Diotima instructs Socrates to listen closely as she is about to reveal the purpose to those who have been

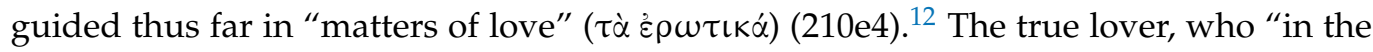
right order and correctly," grasped beautiful things will "all of a sudden" (દ่ $\left.\alpha^{i} \varphi \vee \eta \zeta\right)$ catch a glimpse of something divine: Beauty itself (210e6-211a1). ${ }^{13}$ Unlike beautiful things, Beauty itself always is, and in phrasing reminiscent of the training exercise of Parmenides, Diotima claims Beauty itself "neither comes to be nor passes away, neither waxes nor wanes" (211a2-3). ${ }^{14}$ Beauty itself is "always one in form" and unconditionally beautiful

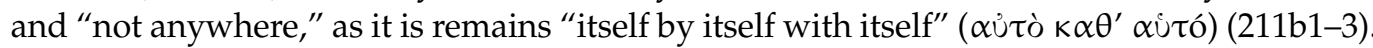
The lover begins with beautiful things, and "using them like rising stairs," ascends to Beauty itself, and finally, "he comes to know just what it is to be beautiful" (211c4-8). ${ }^{15}$ Thus, Diotima's account of love and the Beautiful climaxes with the lover assimilating to the beloved: Beauty itself. "If any human being could become immortal," Diotima concludes, then it would be him "who has given birth to true virtue and nourished it" (212a8-212b1). Hence, $\varepsilon^{\prime} \xi \alpha i \varphi \vee \eta \zeta$ appears at the highpoint of the Symposium as Plato describes a spiritual awakening or illumination experience.

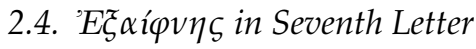

Plato's Seventh Letter illustrates the power and necessity of friendship. In his opening address to "the friends and followers of Dion," Plato attempts to persuade the supporters of the now deceased Dion to refrain from a violent revolt against the Syracuse regime headed by Dionysius II. ${ }^{16}$ In doing so, Plato offers an autobiographical account of his own political ambitions as a young man and his and Dion's prior attempts at reforming both 
Syracuse and the whole of Sicily by instituting the best laws. ${ }^{17}$ Following a brief description of the aftermath of the Peloponnesian war and the events leading to the execution of his "friend Socrates" (325b6), Plato reveals that through reflection and maturity, he realized "it was impossible to do anything without friends" (325d1)..$^{18}$

Amid what secondary sources often refer to as the "epistemological digression," Plato introduces the "true doctrine" ( $\lambda$ ó$_{0} \circlearrowleft \dot{\alpha} \lambda \eta \theta \dot{\eta} \varsigma$ )—a methodical, step-by-step process examining name, definition, image, knowledge, and the object itself-which generates ascending levels of understanding (342a3). He claims he has explained the true doctrine before, but he elects to explain it once more so the friends of Dion might gain a better understanding of philosophical education. The earnest back-and-forth, give-and-take discussion of friends doing philosophy is crucial. In the end, progress in the true doctrine results in a conversion of sorts insofar as this philosophical friendship generates a life of selfsustained philosophical activity. Plato depicts the shared intensity and central aim of the friendship as follows: "after long-continued intercourse between teacher and pupil in joint pursuit of the subject, suddenly ( $\left.\varepsilon^{\xi} \xi \alpha \varphi \vee \vee \zeta\right)$, like light flashing forth when a fire is kindled, it is born in the soul and straightaway nourishes itself" (341c8-d1). Thus, friendship and philosophical education sparks a sudden $\left(\dot{\varepsilon} \xi \alpha \alpha^{\prime} \varphi v \eta \zeta\right)$ illumination experience. ${ }^{19}$ The transformation of the true doctrine's participant commences a new beginning as the participant emerges "on fire with philosophy" and capable of self-sustained study. ${ }^{20}$

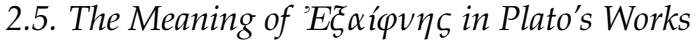

While the fifty-nine appearances of $\varepsilon^{\xi} \xi \alpha i \varphi \vee \eta \varsigma$ in extant Greek literature prior to and contemporaneous with Plato often evince a foreboding quality, Plato's use of "the sudden" demonstrates a radical shift in meaning and significance. In the Seventh Letter, $\varepsilon \xi \alpha i \varphi \vee \eta \zeta$ represents the sudden illumination experience stimulating and solidifying the philosopher's desire to pursue wisdom with a burning enthusiasm, just as $\dot{\varepsilon} \xi \alpha i \varphi v \eta \varsigma$ in the Symposium signifies the sudden revelation of Beauty itself. The allegory of the cave from Republic VII finds $\varepsilon^{\prime} \xi \alpha^{\prime} \varphi \vee \eta \zeta$ marking the moment of emancipation as the prisoner is compelled suddenly to look toward the light of the Good itself, while in Plato's Parmenides, $\varepsilon \xi \alpha i \varphi \vee \eta \varsigma$ functions as the "the instant" - the peculiar place of participation-eternally animating the Ideas. Thus, Plato alters the significance of $\dot{\varepsilon} \xi \alpha i \varphi v \eta \varsigma$ and transforms it into a symbol for the sudden flash of insight that crystallizes the climactic conversion experience engendered by philosophical education. ${ }^{21}$

The most remarkable examples of the thirty-six appearances of $\dot{\varepsilon} \xi \alpha i \varphi \vee \eta \varsigma$ in Plato's works illustrate a methodical, step-by-step process of philosophical education climaxing with a sudden and dramatic conversion experience. This conversion experience mirrors

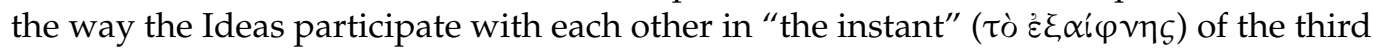
hypothesis of Parmenides. The flash of illumination-"this strange creature" ( $\alpha u ̈ \tau \eta ~ \varphi u ́ \sigma \iota \varsigma$

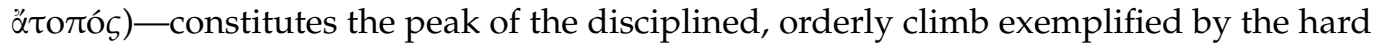
work of character and intellectual training involved in philosophical education. The sudden and striking reorientation "turns the whole soul until it is able to study that which is and the brightest thing that is, namely, the one we call the Good" (Republic VII, 518c7-d1). If we are diligent, thoughtful, and persistent with philosophical exercises, then with equal parts good fortune and good will, perhaps a strange and sudden insight might come to light.

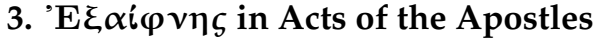

The New Testament, composed originally in common (koเvñ) Greek in the latter half of the first century C.E. and early decades of the second, remains the foundational text of Christianity. Because it was both written in antiquity and in Greek, it stands to reason those figures of speech and tropes characteristic of the ancient Greek philosophical and literary tradition would find their way into Christianity's central text. A product of its time, the New Testament's emergence in antiquity determined its rhetorical and literary approach. As Alexander (2001, p. 1029) reveals: 
Late first century philosophical literature shows that there was a real interest in presenting the lives of the philosophers as templates for living the philosophical life, especially the life (and even more the death) of the martyr-philosopher Socrates. A number of details in Acts would recall this paradigm for Greekeducated readers.

One such detail is the use of $\dot{\xi} \xi \boldsymbol{i} \varphi$ i $\eta$ s. It appears five times in the New Testament, and all the appearances bear a striking similarity to Plato's use of the term. ${ }^{22}$ We highlight the two

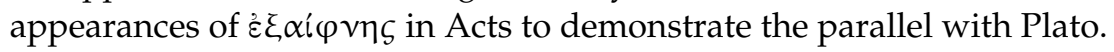

Immediately following the canonical gospels, Acts serves to connect the gospels to Paul's letters. Largely thought to be written by the same Luke of the gospel tradition, Acts presents a smooth transition from the life of Jesus Christ to the earliest Christian community. It holds a special place as the link between Christ's ministry in the gospels and the nascent establishment of Christianity and subsequent proliferation of the religion throughout the Greco-Roman world. The pivotal moment of Acts, and indeed Christianity itself, involves Paul's celebrated conversion experience on the road to Damascus.

This crucial moment mirrors the appearances of '̇ $\xi \alpha i \varphi v \eta \zeta$ in Plato's dialogues insofar as it chronicles a conversion experience as an abrupt flash of understanding quite like the sudden illumination experiences described in Plato's Seventh Letter, Republic, and Symposium. ${ }^{23}$ Acts 9 begins with Paul seeking letters from the high priest that would implicate those belonging to a nascent form of Jewish Christianity called "the Way". Paul intends to marshal these early Christians in Damascus and return them to Jerusalem to face persecution. Consequently, Acts 9:3 depicts Paul's experience as follows: “And as he journeyed, he came near Damascus: and suddenly ( $\xi \xi \alpha i \varphi v \eta \zeta)$ there shined round about him a light from heaven". Jesus addresses Paul and questions his activities. Christ then commands him to enter Damascus to await further instructions, "and for three days [Paul] was without sight, and neither ate nor drank" (Acts 9:9). Paul's transformation is, as Alexander (2001, p. 1039) contends, "a complete change of direction" or simply, a conversion experience.

Likewise, in Acts 22:6, Paul retells his sudden change of direction: "While I was on my way and approaching Damascus, about noon a great light from heaven suddenly

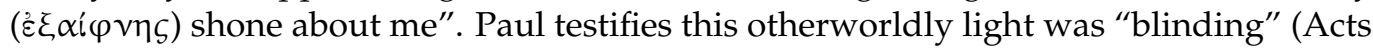
22:11), just as the sun, i.e., the Good, dazzled the liberated prisoner in Plato's allegory of the cave. ${ }^{24}$ Furthermore, in much the same way that Plato describes the sudden reorientation of the soul after a lengthy training process, Paul's conversion, though sudden and miraculous, was preceded by a preparative phase. "The actual explosion was sudden," writes Ferris 1954, 118, "but there was a long fuse burning under the surface which had been lighted years before, and gradually the flame crept nearer and nearer to the explosive center". The fact the author of Acts finds Paul's sudden conversion experience in 9:3 worthy of restating in 22:6 indicates its significance for both the ostensible author, Luke, and the early history of Christianity. It is also highly suggestive insofar as these biblical verses parallel Plato's paradigm: prolonged period of thinking, sudden ( $\xi \xi \alpha i \varphi v \eta \zeta)$ illumination experience, and profound reorientation.

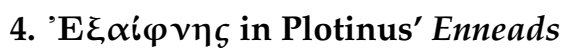

The Platonist par excellence of late antiquity, Plotinus, exhibits a similar employment of $\dot{\varepsilon} \xi \alpha i \varphi v \eta \zeta$. Though Plotinus's treatment of $\varepsilon^{\prime} \xi \alpha i \varphi v \eta \zeta$ is comparatively limited-it materializes in his Enneads only nine times-the positioning of these appearances in contexts mirroring those found in Plato's dialogues suggests, perhaps at the very least, an homage

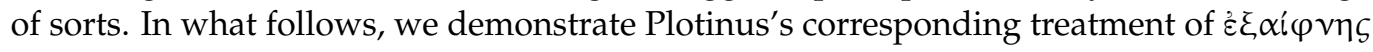
to reveal how it functions as a key term in his philosophical project.

Like Plato, Plotinus inserts દ̇ $\xi \alpha \varphi \varphi \eta\rceil$ in passages depicting the peak of philosophical enlightenment. Many of these appearances relate to the vision of the One, or Good. Plotinus unveils the uniformity of the One and the Good in II.9.5-6: "When we speak of the One and when we speak of the Good we must recognize an identical nature; we must affirm 
that they are the same". The Plotinian One-Good unites the One of Plato's Parmenides and the Good from Republic. ${ }^{25}$ As noted above, both Parmenides and Republic feature significant appearances of $\dot{\xi} \xi \alpha \hat{\imath} \varphi \vee \eta \varsigma$. Rather than considering himself an originator of a distinct philosophy, however, Plotinus viewed his life's work as bringing Platonism to its full and most explicit fruition. In what follows below, we isolate five appearances of $\dot{\xi} \xi \alpha i \varphi \vee \eta \varsigma$ from Enneads V and VI to disclose how Plotinus utilizes this term in ways strikingly similar to those from Plato's dialogues featured above (Plotinus 1984).

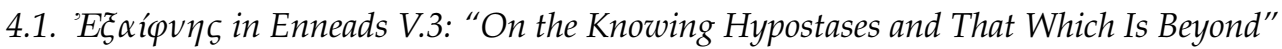

The fifth Ennead as assembled and arranged by Plotinus's student, Porphyry, concerns self-knowledge and intelligible reality. Here, Plotinus ruminates on the relation between human intellect and the Divine Intellect itself. On the one hand, he does not consider it "strange" (光o $\pi \mathrm{o} v)$ to conclude the soul lacks the capacity to think itself. On the other hand, it would indeed be "strange" (宅o $\pi \mathrm{o} v$ ) to conclude the intellect lacks this capacity for self-knowing (V.1.18-19).

V.1 illuminates the three primary hypostases or transcendent sources of reality, i.e., the One-Good, the Divine Intellect, and the World Soul, while V.2 sheds further light on the doctrine and clarifies the continuity of Plotinus's emanation theory. Plotinus then explains how the human intellect unites with the Divine Intellect in V.3 and how this unity relates to self-knowledge. ${ }^{26}$ Nevertheless, this is not the terminus of Plotinus's project. Ultimately, one must move beyond the Divine Intellect and embrace the One-Good. The conclusion of Ennead V's third tractate (V.3.17) depicts this immediate and ineffable illumination experience:

The soul runs over all truths, and all the same shuns the truths we know if someone tries to express them in words and discursive thought; for discursive thought, in order to express anything in words, has to consider one thing after another: this is the method of description; but how can one describe the absolutely simple? But it is enough if the intellect comes into contact with it; but when it has done so, while the contact lasts, it is absolutely impossible, nor has it time to speak; but it is afterwards that it is able to reason about it. One must believe when one has seen, when the soul suddenly ( $\left.\varepsilon_{\xi} \alpha \dot{i} \varphi \vee \eta \zeta\right)$ takes light: for this is from him and he is it; we must think that he is present when, like another god whom someone called to his house, he comes and brings light to us: for if he had not come, he would not have brought the light.

Echoing the $\varepsilon^{\prime} \xi \alpha i \varphi v \eta \zeta$ examples in Plato's works, Plotinus offers an account of a noetic ascent climaxing with sudden enlightenment. In Plato's Symposium, Diotima describes the "sudden" ( $\left.\xi^{\xi} \alpha \hat{i} \varphi \vee \eta \zeta\right)$ emergence of Beauty itself leading one to know "just what it is to be beautiful," while Plotinus speaks of the soul "suddenly" ( $\dot{\xi} \alpha i \varphi v \eta \varsigma)$ experiencing the One-Good and reasoning afterwards about what it means to be good. ${ }^{27}$

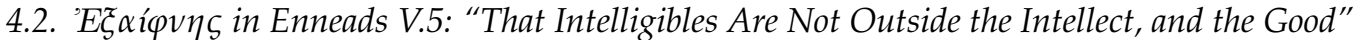

Likewise, in V.5.3, Plotinus equates the vision of the One-Good, i.e., "the First," with a hierarchical sequence of beauty analogous to the ladder of love passages from Plato's Symposium:

For the First in its progress could not take its stand upon something soulless, nor immediately upon Soul, but there must be an inconceivable beauty going out before it, as in the procession before a great king the lesser ranks go first, and then in succession the greater and after them the yet more majestic and the court which has still more of royal dignity, and then those who are honored next after the king; and after all these the great king himself is suddenly ( $\left.\dot{\xi} \xi \alpha_{i}^{\prime} \varphi \vee \eta \varsigma\right)$ revealed, and the people pray and prostrate themselves before him.

In V.5.7, Plotinus writes of Divine Intellect coalescing with the One in a mystical fusion: 
Just so Intellect, veiling itself from other things and drawing itself inward, when it is not looking at anything will see a light, not a distinct light in something different from itself, but suddenly ( $\varepsilon \xi \alpha i \varphi \vee \eta \zeta)$ appearing, alone by itself in independent purity, so that Intellect is at a loss to know whence it has appeared, whether it has come from outside or within, and after it has gone away will say, 'It was within, and yet it was not within.'

The above passages reflect accounts of mystical experiences generally insofar as they depict the spiritual synthesis obtaining between what once were two separate entities. Hadot 1998, 58 , describes this spiritual event-the union of self and the One-Good-as founded upon the equivalence of the One-Good and the self's "pure, simple, undecomposable presence". Stated another way, this spiritual synthesis equates to Platonic participation.

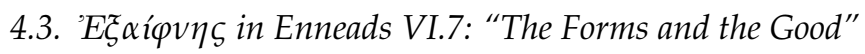

In VI.7.34, Plotinus describes further the soul's assimilation with the One-Good. The passage below presents the most explicit integration of soul and the Good in the Plotinian corpus. "Once the soul has no more possessions, and has stripped herself of all form," writes Hadot 1998, 57, "she is at one with the object of her love and becomes the Good. She is the Good". Again, the soul's assimilation to the Good parallels with Platonic participation, especially with Diotima's account in Symposium. Like Plato, Plotinus captures the abrupt

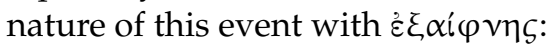

But when the soul has good fortune with it, and it comes to it, or rather, being there already, appears, when that soul turns away from the things that are there, and has prepared by making itself as beautiful as possible and has come to likeness - the preparation and the adornment are clearly understood, I think, by those who are preparing themselves-and it sees it in itself suddenly ( $\dot{\xi} \xi \alpha \varphi \varphi \vee \eta \varsigma$ ) appearing - for there is nothing between, nor are there still two but both are one; nor could you still make a distinction while it is present; lovers and their beloveds here below imitate this in their will to be united-it does not still perceive its body, that it is in it, and does not speak of itself as anything else, not man, or living thing, or being, or all, for the contemplation of these would be somehow disturbing, and it has no time for them nor wants them, but it has been seeking it, and meets that when it is present, and looks at that instead of itself; but it has not even time to see who the soul is that looks. There, truly, it would not exchange this for anything in the world, not even if someone handed over the whole universe to it, because there is nothing still better, and nothing that is more a good; for it does not run up higher, and all the other things are on its way down, even if they are in the realm of above. So then it has the ability to judge rightly and to know that this is what it desired, and to establish that there is nothing better than it.

The inclusion of $\dot{\xi} \alpha \hat{\imath} \varphi \vee \eta \zeta$ and the poetic construal of "both are one" suggests Platonic participation. Furthermore, the above passage might very well be an instance of Plotinus hinting at his own mystical experiences. According to Porphyry, Plotinus achieved this mystical union four times during his life. Plotinus himself states in Enneads IV.8.1: "Many times it has happened: Lifted out of the body into myself; becoming external to all other things; beholding a marvelous beauty; then, more than ever, assured of community with the loftiest order; living the noblest life, acquiring identity with the Divine". Again, the context and language reflect the passages from Plato's dialogues that suggest participation with the Idea as happening "all of a sudden" (દ) $\alpha$ í $\varphi \vee \eta \zeta)$.

In addition, from "The Forms and the Good" Plotinus writes in VI.7.36:

It is there that one lets all study go; up to a point one has been led along and settled firmly in beauty and as far as this one thinks that in which one is, but is carried out of it by the surge of a wave of Intellect itself and lifted on high by a kind of swell and sees suddenly ( $\xi \alpha \alpha \varphi \vee \eta \varsigma)$, not seeing how, but the vision fills 
his eyes with light and does not make him see something else by it, but the light itself is what he sees.

Philosophical progress in Plotinus's system generates the same sudden illumination experience as depicted in the ह̇ं $\alpha i \varphi \vee \eta \varsigma$ passages of Plato's dialogues. In his commentary on the above passage from Ennead VI, Hadot 1998, 62, explains, "For Plotinus, as for Plato, vision consists in contact between the inner light of the eye and exterior light. Yet Plotinus concludes from this that when vision becomes spiritual, there is no longer any distinction between inner and outer light". This assimilation process-represented conceptually with the appearance of ध $\xi \alpha i \varphi \vee \eta \varsigma$-delineates Plotinus's account of the soul's ascent to the divine described by Plato in the passages discussed above.

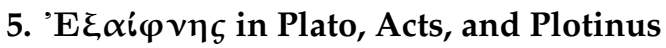

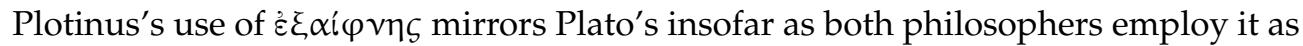
a sign for a transformative illumination experience, although of the two, only Plato-in his Parmenides - offers a conceptual treatment of the term. Both thinkers describe the assimilation of Idea and soul (although Plotinus does so much more explicitly), and both

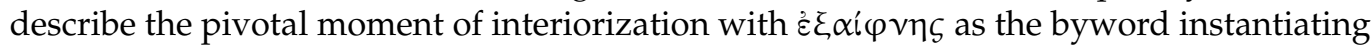
this mystical union.

From the thematic presentation of "the instant" ( $\left.\hat{o ̀ ~}^{\varepsilon} \xi \alpha i \varphi v \eta \zeta\right)$ in Parmenides, to the prisoner "suddenly" ( $\xi \xi \alpha i \varphi \vee \eta \zeta)$ liberated in the allegory of the cave, to the revelation of Beauty itself happening "all of a sudden" ( $\varepsilon \xi \alpha i \varphi v \eta \varsigma)$ in Symposium, to the peak of

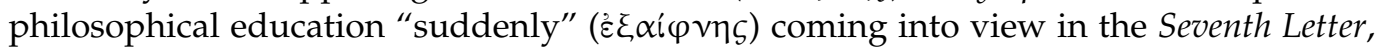
$\xi^{\prime} \xi \alpha_{i} \varphi v \eta \varsigma$ pops up in some of the most notable passages of Plato's works. Likewise, Paul's conversion experience on the road to Damascus repeated twice in Acts of the Apostles

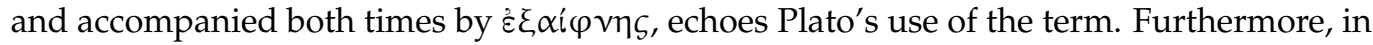

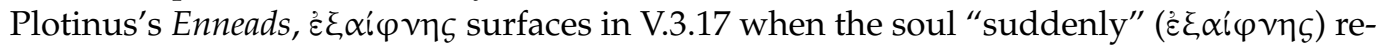
ceives the light of the One-Good, in V.5.3 as the majestic One-Good "suddenly" ( $\xi \xi \alpha i \varphi v \eta \zeta)$

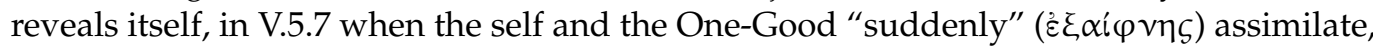
again in VI.7.34 as the soul "suddenly" ( $\xi \xi \alpha \varphi \varphi \vee \zeta)$ embraces the One-Good, and finally in VI.7.36 as the spiritually immanent self "suddenly" ( $\left.\xi \alpha_{i} \varphi \vee \eta \zeta\right)$ merges with the divine transcendence of the One-Good.

Whether Plato inspired succeeding thinkers regarding the use of $\dot{\varepsilon} \xi \alpha i \varphi v \eta \varsigma$ or if these curious subsequent appearances of the term signify a shared insight lingers as an open question. On the one hand, the question concerning the intention of the author of Acts and if he was indeed consciously trading upon Plato's notion of $\dot{\varepsilon} \xi \alpha i \varphi v \eta \zeta$ remains unanswerable, highly suggestive though it may be. On the other hand, Plotinus's appropriation of Plato's philosophy is undeniable, as Plotinus himself readily acknowledges in V.1.8: "these statements of ours are not new; they do not belong to the present time, but were made long ago, not explicitly, and what we have said in this discussion has been an interpretation of them, relying on Plato's own writings for evidence that these views are ancient". Whether Plotinus's understanding of Platonic philosophy corresponds to Plato's own or if Neoplatonism is an altogether new and distinctive philosophy, of course, remains a matter of scholarly dispute. Nevertheless, as the most renowned Platonist of late antiquity, Plotinus saw his life's work as clarifying and communicating Plato's thought for a new generation of philosophers. Like Plato, he sought and discovered eternity in the transitory. Thus, the emergence of "this strange creature" — surprise.

\section{Conclusions}

Although the above examples offer a transcendent, otherworldly kind of conversion experience narrative, when Plato describes the illumination of the highest realities in his Seventh Letter, he warns those reading this account against "an exaggerated and foolish elation, as if they had discovered something grand" (341e5-6). Likewise, we believe something approximating conversion experiences occur rather frequently in all aspects of everyday 
life. ${ }^{28}$ For example, it occurs when we suddenly understand a concept or an argument we previously struggled to grasp or when we have an insight about a particular topic, e.g., human nature, the problem of evil, etc., that we have been studying for some time.

On the other end of the spectrum, the illumination experience can also take the form of a mystical, ecstatic, profound encounter with the divine described in the passages from Plato, Paul's conversion experience in Acts, and Plotinus' Enneads. Presumably, we can undergo a range of different conversion experiences from the more ordinary ones in the classroom to the more extraordinary ones described in these texts. Nevertheless, the common denominator would seem to be a "flash of lightning illumining the darkness," as Augustine describes it in his City of God (Augustine 1950, IX.16). ${ }^{29}$ Thus, "illumination" and "conversion" need not designate one specific type of experience but rather an entire range or spectrum of experiences. Perhaps we all partake of certain smoldering truths, which, like a spark, might ignite suddenly and illuminate a different way. ${ }^{30}$

Author Contributions: Writing-Original draft: J.C., J.J.R. and K.S. All authors have read and agreed to the published version of the manuscript.

Funding: This research received no external funding.

Institutional Review Board Statement: Not applicable.

Informed Consent Statement: Not applicable.

Conflicts of Interest: The authors declare no conflict of interest.

\section{Notes}

The Latin verb convertere means "to turn around; to transform".

Nock (1933, p. 14), argues that outside of Christianity and Judaism, the "only context" one could discover conversion experiences in ancient literature appears in the realm of philosophy. For example, Apollodorus, the narrator of Plato's Symposium, examines himself before discovering philosophy. According to Apollodorus, prior to meeting Socrates, he "drifted aimlessly," and critiques his former way of life: "Of course, I used to think that what I was doing was important, but in fact I was the most worthless man on earth - as bad as you are this very moment: I used to think philosophy was the last thing a man should do" (173a). Following his conversion to the philosophical life, though, Apollodorus says his "greatest pleasure comes from philosophical conversation, even if I'm only a listener" (173c).

3 More recent scholarship on the pivotal role of $\dot{\xi} \xi \alpha i \varphi v \eta \varsigma$ in Plato's works include (McGinley 2009; Gordon 2010; Rangos

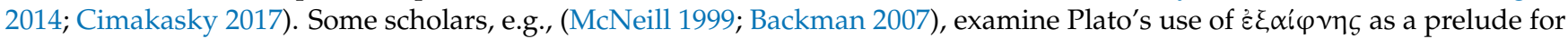
interpretations of similar concepts such as Martin Heidegger's "moment of vision".

4 Our friend Dakota Eckenrode once suggested it is possible ancient Greek readers, or more accurately, listeners, would have recognized $\varepsilon^{\xi} \xi \alpha \hat{\imath} \varphi \vee \eta \varsigma$ for its worrying connotations when it emerges in Plato's dialogues, and thus the dark undertones of the term itself would attune the reader more intensely to the passage in which it appears.

5 If the Ideas are conceived as atemporal, then the use of the word "motion" and its cognates should be understood analogically.

6 For a more comprehensive treatment of participation among the Ideas, see especially “The Enduring Charm of Plato's Unwritten Doctrines" by Ron Polansky and Patrick Macfarlane in Philosophy, Competition and the Good Life. Furthermore, Michael Wiitala's "The Argument against the Friends of the Forms Revisited: Sophist 248a4-249d5" provides an account of how the Ideas affect and particpate with each other (Polansky and MacFarlane 2005; Wiitala 2018).

7 Of the scholars designating it as the third hypothesis, most notable are the Neoplatonists. Many commentators, e.g., (Cornford 1957, p. 194; Meinwald 1991, pp. 124-29; Miller 1986, 251n53; Sayre 1996, pp. 240-41; Scolnicov 2003, p. 134; Turnbull 1998, p. 112), count eight hypotheses. Allen (1983, p. 261) tallies four hypotheses with two deductions each, except for the first hypothesis with three deductions. The Neoplatonists, e.g., (Proclus 1987, pp. 402-3), typically count nine hypotheses, with the numbering relating to their theory of emanation.

8 When Plato employs "three" or "third" in other dialogues, it is often at a point of a dialogue's crescendo, or simply, an indication a significant breakthrough has occurred. Plotinus, in Ennead V.1.8, links Plato's use of three with his theory of emanation: "This is the reason why Plato says that all things are threefold 'about the king of all' — he means the primary realities—and 'the second about the second and the third about the third.' But he also says that there is a 'father of the cause,' meaning Intellect by 'the cause:' for Intellect is his craftsman; and he says that it makes Soul in that 'mixing-bowl' he speaks of. And the father of Intellect which is the cause he calls the Good".

9 In contrast to Aristotle's "now" ( $v \tilde{u} v)$ as presented in Physics iv.11-13, Plato's "instant" ( $\left.\varepsilon_{\xi} \alpha \dot{i} \varphi v \eta \zeta\right)$ stands outside of time. Aristotle's "now" provides an orderly account of the division and constancy of continuous and linear time. Plato's "instant," in 
contrast, is as Sayre (1996, p. 248) explains, a "disruption ... that is required for change to take place at all". Thus, Aristotle's conception of "the now" offers an organized, structured view of time, while Plato's "instant" reveals a temporality interrupted, disrupted, and pervaded by timelessness.

"Again, the crucial point at [156c6-d1] is that there is a being that is not in time," explains (Sanday 2015, p. 144), "and that the 'one' must 'be' in a way that is not temporally determinate."

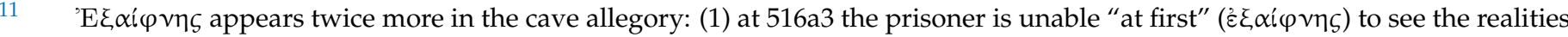
outside the cave due the blinding light of the sun, and (2) at 516e3 when the prisoner "suddenly" ( $\left.\varepsilon^{\prime} \xi \alpha^{\prime} \varphi v \eta \zeta\right)$ returns to the darkness of the cave. Our friend, Ron Polansky, suggests all three appearances of $\varepsilon \xi \alpha i \varphi v \eta \varsigma$ constitute the vision of the Good.

12 In relating the hypotheses of Parmenides with "the final and highest mystery" of love, Gordon (2010, p. 277), argues “Diotima's own account of erotic fulfillment is itself a hypothesis. Her description of the person who might succeed in grasping the idealized objects of eros is expressed in conditional or hypothetical terms, relying on the optative mood and several 'if' clauses". See especially Symposium 211d1-212b1.

13 Allen (1991, p. 82), links the sudden revelation of Beauty itself with ancient Greek religious practices: "Beauty itself ... is revealed to the lover 'suddenly,' 'in an instant,' in an act of intellectual intuition, as the sacred objects of the mystery religions were suddenly revealed to the eyes of the worshippers in a blaze of light".

14 In fact, the conceptual framework and language that Diotima employs to describe Beauty itself in Symposium 211a2-b5 mirrors the training exercise of Parmenides. Miller 1986, 194 affirms that "there is a distinctly Parmenidean cast to Diotima's account of the Beautiful".

15 Rosen (1999), xx observes "the vision of the beautiful itself seems to have as a direct consequence, not speeches, but true instances of virtue, or what one may fairly call a beautiful soul".

16 The status of the Seventh Letter — whether it is genuinely Plato's or a skillful forgery-remains a matter of scholarly dispute. Nevertheless, regarding Plato's efforts to persuade Dion's friends against a violent revolt, Lewis (2000, p. 24) contends: “If we take this rhetorical element with sufficient seriousness, we will see that the content of the letter is fully consistent with the teachings of the political dialogues, a point that tells in favor of the authenticity of the letter". In a similar vein, the use of $\varepsilon \xi \alpha i \varphi \vee \eta \zeta$, in a context mirroring other appearances in the Platonic corpus, would likewise support the authenticity of the Seventh Letter.

17 Morrow (1929, p. 327) writes concerning the Seventh Letter, "Historians from Plutarch to Eduard Meyer have made free and confident use of its historical material for reconstructing the history of Syracuse in the fourth century, and therefore may be said to have accepted it as an authentic document".

18 Regarding the letter's "rhetorical structure," Lewis (2000,p. 25) concludes, "the aim of the letter is protreptic". Plato attempts to turn Dion's associates away from political discord and violence and toward friendship and political concord. In other words, Plato attempts to convert Dion's friends to a better perspective.

19 Concerning the conversation preceding the conversion experience, Morrow $(1929$, p. 344) contends, "But dialectic at its best is only a preparation of the mind for an 'illumination' (ह้ $\lambda \alpha \mu \psi \iota \varsigma)$. Without this experience all the preceding labor is in vain". Similarly, Sayre (2002, p. 227) argues "Plato wrote most of his major dialogues as teaching instruments to guide the attentive reader to the kind of insight of which he spoke in the Seventh Letter".

20 During a discussion of recollection from Meno 81d1-4, Socrates claims "nothing prevents a man, after recalling one thing only-a process men call learning-from discovering everything else for himself, if he is brave and does not tire of the search".

21 Gregory Vlastos, in his Socrates: Ironist and Moral Philosopher (Vlastos 1991, pp. 21-44) accounts for the transformation the meaning of "irony" underwent following the emergence and popularity of Plato's Socrates. Prior to Socrates, Vlastos argues, irony simply meant "deceitful" or "dissembling," but following Socrates irony "shed completely its disreputable past" and became the "perfect

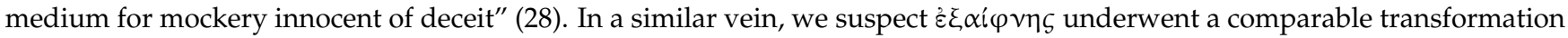
due to the influence and popularity of Plato's dialogues.

22 In addition to the two appearances in Acts, every instance of $\dot{\varepsilon} \xi \alpha i \varphi \vee \eta \zeta$ in the New Testament signifies the revelation or presence of divinity. See Mark 13:35-37; Luke 2:10-14; and Luke 9:37-43 in Coogan (2001).

23 Paul's conversion should be thought of as an abrupt character change, and not as a shifting of religious identification. "The term 'conversion' is anachronistic and misleading," argues Alexander (2001, p. 1039), "if we think of it in terms of a change from one religion to another. Christianity was not at this stage a distinct religion in the modern sense but a sect within Second Temple Judaism, promoting one among a number of contested Jewish identities".

24 "Ironically," Keener (2020, p. 279) points out, "Paul's blindness correlates with his new spiritual sight".

25 "For the Neoplatonists," explains Hadot (1998, p. 72), "the terms Good and One are used interchangeably to designate the first principle. For the sage to have knowledge of the Idea of the Good 'near at hand' means that he can, thanks to assiduous exercise, call it to mind at each and every moment, realize the identity of the best part of himself with the Principle of all things, and thereby become indifferent to external circumstances". In a similar vein, Polanyi $(2009$, p. 21) argues that "true knowledge of a theory can be established only after it has been interiorized and extensively used to interpret experience". 
According to Henderson (1984, p. 69), V.3 represents the "most fully developed and clarified stage of Plotinus' long reflection upon human nature and human thinking". See also (Corrigan (2004) and Deck (1967)).

As documented by Diogenes Laertius (1972, p. 329), the rather curious subtitle for the Symposium is "On the Good". In other words, one might expect the subtitle of Symposium to be "On Love," or "On Beauty" just as the other subtitles, e.g., the subtitle for Parmenides is "On Ideas," are fairly obvious identifications of the topic discussed.

"A certain tendency to insanity has always attended the opening of the religious sense in men," writes Emerson (1981) in his Over-Soul, "as if blasted with excess of light. The trances of Socrates; the union of Plotinus; the vision of Porphyry; the conversion of Paul; the aurora of Behmen; the convulsions of George Fox and his Quakers; the illuminations of Swedenborg, are of this kind. What was in the case of these remarkable persons a ravishment, has, in innumerable instances in common life, been exhibited in less striking manner" (199). See also Irwin (2018).

Augustine famously documents his own conversion as happening suddenly in Confessions viii. Upon hearing a mysterious child's voice chant "tolle lege, tolle lege," Augustine recites Romans 13:13-14, and describes his illumination experience: "Suddenly (statim), the end of the sentence was like a light of sanctuary poured into my heart; every shadow of doubt melted away" (8.12.29).

We would like to thank the editors and two anonymous referees for many helpful suggestions. We would also like to express our gratitude to the members of our virtual Plato reading group: John Fritz, Sharon Schwarze, Ron Polansky, John Cordes, Crystal Anderson, David Hoinski, Kelsey Ward, Brandon Nelson, Colin Smith, Christopher Brady, Sarah Richards, Clayton Bohnet, Tamarah Smith, Emilia Kozlovsky, Maria Hromcenco, Ewan Park, and John Doyle.

\section{References}

Alexander, Loveday. 2001. "Acts" in Barton and Muddiman eds. Available online: https://global.oup.com/academic/product/theoxford-bible-commentary-9780199277186?cc=cn\&lang=en\& (accessed on 4 October 2021).

Allen, R. E. 1983. Plato's Parmenides. Minneapolis: University of Minnesota Press.

Allen, R. E. 1991. The Symposium. New Haven and London: Yale University Press.

Augustine. 1950. The City of God. New York: Modern Library.

Augustine. 1998. The Confessions. New York: Vintage Spiritual Classics.

Backman, Jussi. 2007. All of a Sudden: Heidegger and Plato's Parmenides. Epoche 11: 393-408. [CrossRef]

Cimakasky, Joe. 2017. The Role of Exaiphnes in Early Greek Literature: Philosophical Transformation in Plato's Dialogues and Beyond. Lanham: Lexington Books.

Coogan, Michael D., ed. 2001. The New Oxford Annotated Bible. Oxford: Oxford University Press.

Cornford, Francis M. 1957. Plato and Parmenides. New York: The Liberal Arts Press.

Corrigan, Kevin. 2004. Reading Plotinus: A Practical Introduction to Neoplatonism. Purdue: University Press.

Deck, John N. 1967. Nature, Contemplation, and the One: A Study in the Philosophy of Plotinus. Toronto: University of Toronto Press.

Emerson, Ralph Waldo. 1981. Emerson's Essays. New York: Harper \& Row.

Gordon, Jill. 2010. Erotic Desire and Courage in Plato's Parmenides. Ancient Philosophy 30: 261-88. [CrossRef]

Hadot, Pierre. 1998. Plotinus or the Simplicity of Vision. Chicago: The University of Chicago Press.

Henderson, Jeffrey, ed. 1984. The Enneads. A. H. Armstrong, trans. Cambridge: Harvard University Press.

Irwin, William. 2018. God Is a Question, Not an Answer: Finding Common Ground in Our Uncertainty. New York: Rowman \& Littlefield.

Keener, Craig S. 2020. Acts: New Cambridge Biblical Commentary. Cambridge: Cambridge University Press.

Laertius, Diogenes. 1972. Lives of Eminent Philosophers. Cambridge: Harvard University Press.

Lewis, V. Bradley. 2000. The Rhetoric of Philosophical Politics in Plato's 'Seventh Letter'. Philosophy and Rhetoric 33: 23-38. [CrossRef]

McGinley, John W. 2009. The Dreadful Symmetry of the Good. Bloomington: iUniverse, Inc.

McNeill, William. 1999. The Glance of the Eye. Albany: State University of New York Press.

Meinwald, Constance C. 1991. Plato's Parmenides. Oxford: Oxford University Press.

Miller, Mitchell H. 1986. Plato's Parmenides: The Conversion of the Soul. Princeton: Princeton University Press.

Morrow, Glenn R. 1929. The Theory of Knowledge in Plato's Seventh Epistle. The Philosophical Review 38: 326-49. [CrossRef]

Nock, A.D. 1933. Conversion: The Old and the New in Religion from Alexander the Great to Augustine of Hippo. Baltimore: The Johns Hopkins University Press.

Plotinus. 1984. The Enneads. Edited by Jeffrey Henderson. Cambridge: Harvard University Press.

Polansky, Ron, and Patrick MacFarlane. 2005. Philosophy, Competition and the Good Life. Edited by K. Boudouris and Kostas Kalimtzis. Athens: Ionia Publication, vol. 2, pp. 262-71.

Polanyi, Michael. 2009. The Tacit Dimension. Chicago: The University of Chicago Press.

Proclus. 1987. Commentary on Plato's Parmenides. Translated by Glenn R. Morrow, and John M. Dillon. Princeton: Princeton University Press.

Rangos, Spyrido. 2014. Plato on the Nature of the Sudden Moment, and the Asymmetry of the Second Part of the Parmenides. Dialogue 53: 538-74. [CrossRef]

Rosen, Stanley. 1999. Plato's Symposium. South Bend: St. Augustine's Press.

Sanday, Eric. 2015. A Study of Dialectic in Plato's Parmenides. Evanston: Northwestern University Press. 
Sayre, Kenneth M. 1996. Parmenides' Lesson: Translation and Explication of Plato's Parmenides. Notre Dame: University of Notre Dame Press.

Sayre, Kenneth M. 2002. Plato's Literary Garden. Notre Dame: University of Notre Dame Press.

Scolnicov, Samuel. 2003. Plato's Parmenides. Berkeley and Los Angeles: University of California Press.

Turnbull, Robert G. 1998. The Parmenides and Plato's Late Philosophy. Toronto: University of Toronto Press.

Vlastos, Gregory. 1991. Socrates, Ironist and Moral Philosopher. Ithaca: Cornell University Press.

Wiitala, Michael. 2018. The Argument against the Friends of the Forms Revisited: Sophist 248a4-249d5. Apeiron 51: 171-200. 